\title{
Competition Between Drought-Tolerant Upland Rice Cultivars AND WEEDS UNDER WATER STRESS CONDITION ${ }^{1}$
}

\author{
Competição entre Cultivares de Arroz de Terras Altas Tolerantes à Seca e Plantas Daninhas sob \\ Condição de Estresse Hídrico
}

\author{
CERQUEIRA, F.B. ${ }^{2}$, ERASMO, E.A.L. ${ }^{3}$, SILVA, J.I.C. ${ }^{4}$, NUNES, T.V. ${ }^{5}$, CARVALHO, G.P. ${ }^{6}$, and \\ SILVA, A.A. ${ }^{7}$
}

\begin{abstract}
The objective of this study was to evaluate the competitiveness of two cultivars of upland rice drought-tolerant, cultured in coexistence with weed $S$. verticillata, under conditions of absence and presence of water stress. The experiment was conducted in a greenhouse at the Experimental Station of the Universidade Federal de Tocantins, GurupiTO Campus. The experimental design was completely randomized in a factorial $2 \times 2 \times 4$ with four replications. The treatments consisted of two rice cultivars under two water conditions and four densities. At 57 days after emergence, were evaluated in rice cultivars and weed S. verticillata leaf area, dry weight of roots and shoots and total concentration and depth of roots. Was also evaluated in rice cultivars, plant height and number of tillers. Water stress caused a reduction in leaf area, the concentration of roots and vegetative components of dry matter (APDM, and MSR MST) of rice cultivars and Jatoba Catetão and weed S. verticillata. The competition established by the presence of the weed provided reduction of all vegetative components (MSPA, and MSR MST) of cultivars and Jatoba Catetão. It also decreased the number of tillers, the concentration of roots and leaf area. At the highest level of weed competition with rice cultivars, a greater decrease in vegetative components and leaf area of culture, regardless of water conditions.
\end{abstract}

Keywords: Spermacoce verticillata, interference, Oryza sativa.

\begin{abstract}
RESUMO - O objetivo deste trabalho foi avaliar a capacidade competitiva de dois cultivares de arroz de terras altas tolerantes à seca, cultivados em convivência com a planta daninha $\mathbf{S}$. verticillata, sob as condições de ausência e presença de estresse hídrico. O experimento foi instalado em casa de vegetação, na Estação Experimental da Universidade Federal do Tocantins, Campus Gurupi-TO. O delineamento experimental utilizado foi o inteiramente casualizado, em esquema fatorial $2 \times 2 \times 4$, com quatro repetições. Os tratamentos foram constituidos de dois cultivares de arroz, sob duas condições hidricas e quatro densidades. Aos 57 dias após a emergência, foram avaliados nos cultivares de arroz e na planta daninha $\mathbf{S}$. verticillata: área foliar, matéria seca das raizes e da parte aérea e total, concentração e profundidade de raízes. Também foi avaliada, nos cultivares de arroz, a altura de plantas e o número de perfilhos. O estresse hídrico promoveu redução da área foliar, da concentração de raizes e da matéria seca dos componentes vegetativos (MSPA, MSR e MST) dos cultivares de arroz Jatobá e Catetão e da planta daninha S. verticillata. A competição estabelecida pela presença da planta daninha proporcionou redução de todos os componentes vegetativos (MSPA, MSR e MST) dos cultivares Jatobá e Catetão. Também houve diminuição do número de perfilhos, da concentração de raizes e da área foliar. No maior nível de competição da planta daninha com os cultivares de arroz, ocorreu maior decréscimo dos componentes vegetativos e da área foliar da cultura, independentemente da condição hídrica.
\end{abstract}

Palavras-chave: Spermacoce verticillata, interferência, Oryza sativa.

Recebido para publicação em 2.10.2012 e aprovado em 26.1.2013.

2 Doutorando em Biodiversidade e Biotecnologia da Rede Bionorte, Palmas-TO; < fernando1.981@hotmail.com>; ${ }^{3}$ Professor Adjunto, Dr., Universidade Federal do Tocantins - UFT, Gurupi-TO; ${ }^{4}$ Pós-Doutorando em Agronomia, UFT, Gurupi-TO; ${ }^{5}$ Doutorando em Produção Vegetal, UFT, Gurupi-TO; ${ }^{6}$ Mestrando em Produção Vegetal, UFT, Gurupi-TO; ${ }^{7}$ Graduando em Agronomia, UFT, Gurupi-TO. 


\section{INTRODUCTION}

Upland rice in Brazil presents low average productivity, especially when the main factor is the limitation of water availability. In the Cerrado region, water deficiency has caused inconvenience to many rice farmers due to irregular rainfall distribution.

The cultivation of rice under water stress conditions or reduced water availability during the vegetative and reproductive stages presents a reduction in dry matter production, nutrient contents in the shoot and in the extraction of nutrients until flowering (Crusciol et al., 2003). According to Taiz \& Zeiger (2004), limitation promoted in the leaf area can be considered one of the first responses of plants to water deficit. According to Gerik et al. (1996), the balance between production of assimilates and demand for the development of the reproductive organs becomes severely affected by the reduction in the photosynthetically active leaf area.

Several studies have been conducted by Embrapa Rice and Beans with the objective of selecting superior genotypes of rice, considered drought tolerant and adaptable to the characteristics of the Cerrado areas through morphological and physiological factors responsible for drought resistance. However, other important factors that promote the reduction of the productivity of cultivars of upland rice are sometimes little remembered, being considered a serious problem for the culture; among them, we can highlight the competition established between the culture and weeds, which may derail the cultivation of upland rice.

In Brazil, production losses were caused by plants ranged from $57 \%$ (Azevedo \& Costa, 1988 ) to $96 \%$ (Alcantara \& Carvalho, 1985). These reductions occur because the weeds, in general, have higher competitive ability on the culture. It is noteworthy that the upland rice is a $\mathrm{C}_{3}$ plant that has low light compensation point and low efficiency of water use, compared with $\mathrm{C}_{4}$ plants (Bouhache \& Bayer, 1993).

Silva (2006), avaliando vários autores, afirma que o período em que a cultura do arroz de terras altas deve ser mantida livre da presença de plantas daninhas (período crítico de interferência) situa-se entre 20 e 50 dias após a emergência da cultura.

Silva (2006), evaluating various authors, states that the period in which the culture of upland rice should be kept free of the presence of weeds (critical period of interference) is between 20 and 50 days after crop emergence.

In recent years, research related to the competitive ability of cultivars with weeds are gaining importance, especially since the adoption of competitive genotypes has allowed to reduce production costs, coupled with lower environmental impacts (Balbinot Jr., 2003).

Although it is custom to work with rice cultivars considered drought-tolerant, it is important to have knowledge about their ability to compete when in coexistence with weeds.

This study aimed to evaluate the competitiveness of two varieties of droughttolerant upland rice, cultured in coexistence with the weed Spermacoce verticillata, under conditions of absence and presence of water stress.

\section{MATERIAL AND METHODS}

The experiment was conducted in a greenhouse at the Experimental Station of the Universidade Federal de Tocantins, GurupiTO Campus, during the period from October 27th 2008 to December 27th 2008. The soil used in the experiment was collected in the 0 to $20 \mathrm{~cm}$ layer and is classified as Dystrophic Red-Yellow Latosol (Embrapa, 1999). The physical and chemical characteristics of the soil used in the experiment are shown in Table 1.

The climatological data of temperature and relative humidity were collected through a thermohygrograph, installed inside the greenhouse during the experiment (Figure 1). The experimental units consisted of PVC pipes of $1 \mathrm{~m}$ in length and $300 \mathrm{~mm}$ in diameter.

The experimental design used was completely randomized in a factorial $2 \times 2 \times 4$ scheme with four replications, the treatments consisting of two rice cultivars (Jatoba and Catetão), two water conditions (with and without water stress) and four densities $(0,2$, 
Table 1 - Chemical analysis of the soil (0.0-0.20 cm) of the experimental area, performed on september $20^{\text {th }}, 2008$

\begin{tabular}{|c|c|c|c|c|c|c|c|c|c|c|c|}
\hline \multicolumn{10}{|c|}{ Soil analysis } \\
\hline $\mathrm{Ca}$ & $\mathrm{Mg}$ & $\mathrm{Al}$ & $\mathrm{H}+\mathrm{Al}$ & $\mathrm{K}$ & $\mathrm{K}$ & $\mathrm{P}(\mathrm{mel})$ & Org. Matter & $\mathrm{pH}$ & \multicolumn{2}{c|}{ Sand } & \multicolumn{2}{c|}{ Texture $(\%)$} \\
\hline \multicolumn{2}{|c|}{$\left(\mathrm{cmol} \mathrm{dm}^{-3}\right)$} & & $\left(\mathrm{mg} \mathrm{dm}^{-3}\right)$ & $(\mathrm{ppm})$ & $(\%)$ & $\left(\mathrm{CaCl}_{2}\right)\left(\mathrm{H}_{2} 0\right)$ & Silt & $\mathrm{Clay}$ \\
\hline 1.65 & 0.47 & 0.08 & 3.23 & 0.06 & 21.5 & 0.6 & 3 & 5.25 .6 & 66.9 & 3.8 & 29.3 \\
\hline
\end{tabular}
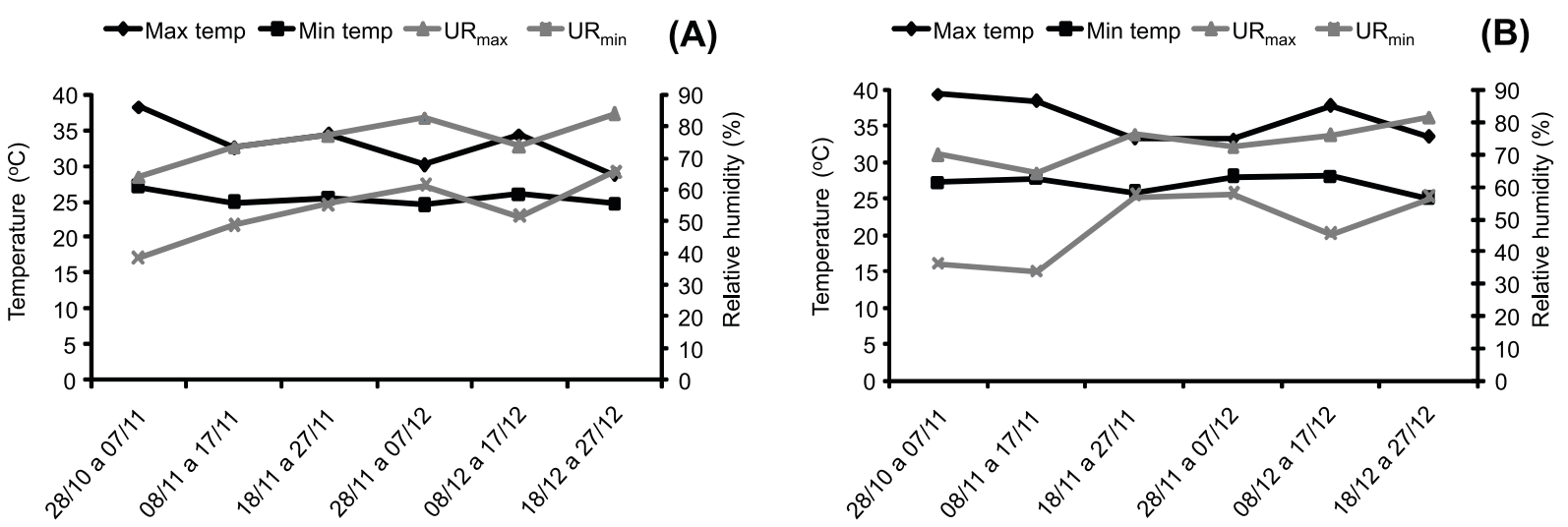

Figure 1 - Mean maximum temperature (Max temp) and minimum (Min temp) in $\left({ }^{\circ} \mathrm{C}\right)$, maximum $\left(\mathrm{UR}_{\max }\right)$ and minimum $\left(\mathrm{UR}_{\min }\right)$ relative air humidity in (\%), every 10 days, collecting at $9 \mathrm{pm}(\mathrm{A})$ and at $3 \mathrm{pm}(\mathrm{B})$, during the period from October to December 2008 in a greenhouse in the town of Gurupi-TOcantins.

4 and 8) of Spermacoce verticillata. The rice density was four plants per experimental unit.

The fertilization was done according to the technical recommendations of Embrapa for the cultivation of upland rice (Embrapa, 2003), and the levels of nitrogen and potassium applications made in installments in presowing and top dressing, at 30 days after emergence (DAE). The sowing of rice cultivars and the weed $S$. verticillata was held on 10/27/ 2008.

Irrigation was divided into two stages; in the first, initiated in the period from October 27th to November 6th 2008, all treatments had the water content in the soil elevated to field capacity. The replacement of water slides for each experimental unit was performed daily, based on the reference evapotranspiration ETo $\left(\mathrm{mm}^{-1 a y}{ }^{-1}\right)$ and the crop coefficient (kc), as proposed by Silva $\&$ Assad (2001), estimating the ETm maximum crop evapotranspiration $\left(\mathrm{mm} \mathrm{day}^{-1}\right)$, by the equation: $\mathrm{ETm}=\mathrm{kC} \times$ ETo.
The second phase began on November 7th, 2008 until December 27th, 2008, in which, from the curve of water retention in the soil (Figure 2), it was determined the amount of water needed for irrigation of rice cultivars; treatments under water stress were established taking into account half of the actual water needed for the crop.

Irrigation management was made based on installation of two tensiometer batteries per

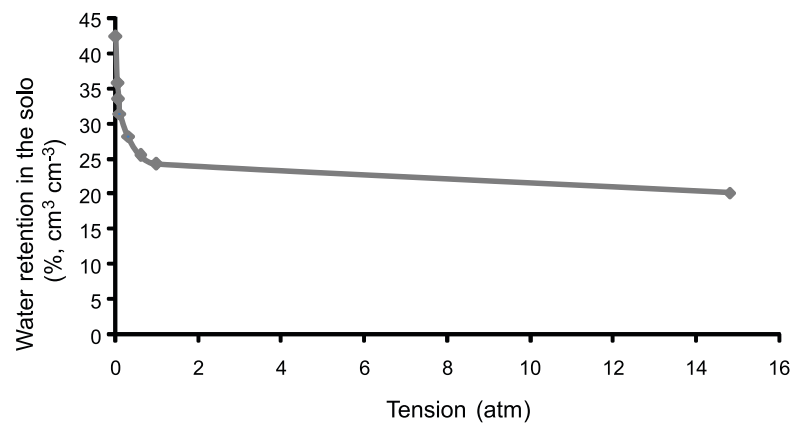

Figure 2 - Curve of water retention in the soil. 
treatment before sowing, totaling 32 batteries, each battery consisting of a tensiometer installed at $15 \mathrm{~cm}$ depth, called the decision tensiometer, and another at $30 \mathrm{~cm}$ for the monitoring of water within the soil column. Soil moisture was monitored daily by the decision tensiometers, being held under appropriate conditions, with matric potential greater than $-0.025 \mathrm{MPa}$ (Stone et al., 1986).

At 57 days after emergence, were evaluated in rice cultivars and the weed S. verticillata: leaf area, dry matter of roots, shoots and total, concentration and depth of roots. We also assessed rice cultivars for plant height and number of tillers.

Plant height was measured with a graduated ruler from the neck of the plant until the end of the longest leaf, with the blade extended. As for the number of tillers, they were counted and we obtained an average of one plant per experimental unit.

The leaf area of rice cultivars and S. verticillata was determined by digital image using a Mitsuca brand camera, model DC7328BR, 7.0 megapixels. According to Camara et al. (1996), this method consists in capturing images of leaves through a camera and their processing by the software SPRING (Georeferenced Information Processing System). The determination of the leaf area was based on the scale (variable) and resolution in which the images were obtained (300 dpi).
To determine the dry matter of rice and $S$. verticillata (shoots, roots and total), the plants were collected, identified, placed in paper bags and placed in an oven at $70{ }^{\circ} \mathrm{C}$ for 72 hours and subsequently, the dry matter was determined.

Roots were separated by species, photographed and, using the process described above, we measured their depth of higher concentration (concentration over $90 \%$ ) as well as the greatest depth reached by the roots using a measuring tape.

Data were subjected to analysis of variance and means were compared by Tukey test at $5 \%$ using the SISVAR program.

\section{RESULTS AND DISCUSSION}

In (Figure 3A, B), it is possible to observe the behavior of the number of tillers per plant of rice cultivars in terms of densities of coexistence with Spermacoce verticillata, under two water conditions.

The largest amount of tillers per plant was observed when cultivars grew without the coexistence of the weed, regardless of water conditions. In the absence of water stress there were values of 14.62 and 14.5 tillers/ plant for cultivars and Jatoba and Catetão, respectively. Under conditions of water stress, these values were 9.81 and 9.87 tillers/plant, respectively, which represents a reduction of 32.91 and $31.90 \%$ in the same order.
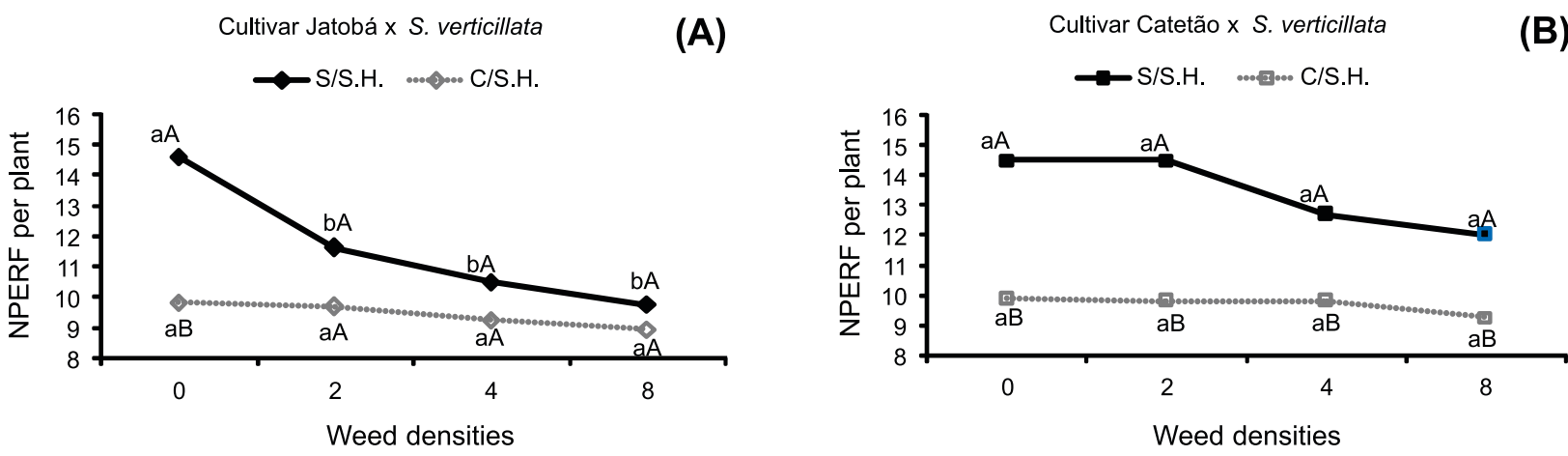

Means followed by the same lowercase letter (between the densities within each water situation) and uppercase (within each density between water conditions) did not differ statistically by Tukey test at $5 \%$ probability.

Figure 3 - Number of tillers (NPERF) by rice plant (Jatoba and Catetão cultivars) grown in coexistence with different densities of Spermacoce verticillata, in conditions without water stress (S/S.H.) and with water stress (C/S.H.). Gurupi-TO, 2008. 
Significant differences between densities within each water condition were identified only in the Jatoba cultivar, among the 0 plants per pot treatment and the others, in the condition without water stress. When comparing the number of tillers produced by the rice crop in each water condition imposed at different densities of coexistence with the weed, there were significant differences in all treatments in the Catetão cultivar and only in the 0 plants per pot treatment in the Jatoba cultivar.

Fornasieri Filho \& Fornasieri (1993) stated that, when the water deficit is intense, tillering can be reduced, affecting the number of stems per planted area. Silva (2006), working with periods of weed interference in the culture of upland rice, found a reduction in the number of tillers of IAC-202 (53.6\%) and Caiapo $(31 \%)$ at harvest when comparing interference of weeds for $70 \mathrm{DAE}$ with control without interference from weeds.

The increased number of $S$. verticillata plants living with the rice culture promoted a growing reduction in the production of tillers, being more evident in the condition of water stress, regardless of the cultivar. However, when measuring the competitive effect of 8 plants per pot compared to 0 plants per pot treatment, it was found that minor reductions in the number of tillers corresponded to the Catetão cultivar, with values of 17.24 and $6.33 \%$ when grown with and without water stress, respectively. In this same situation, the Jatobá cultivar decreased by 33.33 and $8.92 \%$.

The total leaf area (AFT) of rice cultivars with different densities of coexisting $S$. verticillata in two water conditions is shown in (Figures 4A, B). The rice cultivars grown without the coexistence of $S$. verticillata and in the absence of water stress showed higher leaf area, corresponding to 2,974.09 and $2,194.76 \mathrm{~cm}^{2}$ for cultivars Jatoba and Catetão, respectively. The presence of water stress significantly reduced leaf area in the Jatoba cultivar: in $34.06 \%$, whereas the cultivar Catetão, which showed no significant difference, decreased by $12.25 \%$.

The increase in the number of S. verticillata plants living with the rice crop reduced leaf area of plants regardless of water conditions and the cultivar, but always to a lesser extent in the Catetão cultivar.

In the absence of water stress and without the coexistence of the weed, the leaf area of cultivar Jatobá differed significantly from the other treatments where the increased density of the weed while under water stress a significant difference was detected only with the highest level of competition (8 plants per pot). Under the same conditions, the Catetão cultivar presented significance solely for the 8 plants per pot treatment, regardless of water conditions.
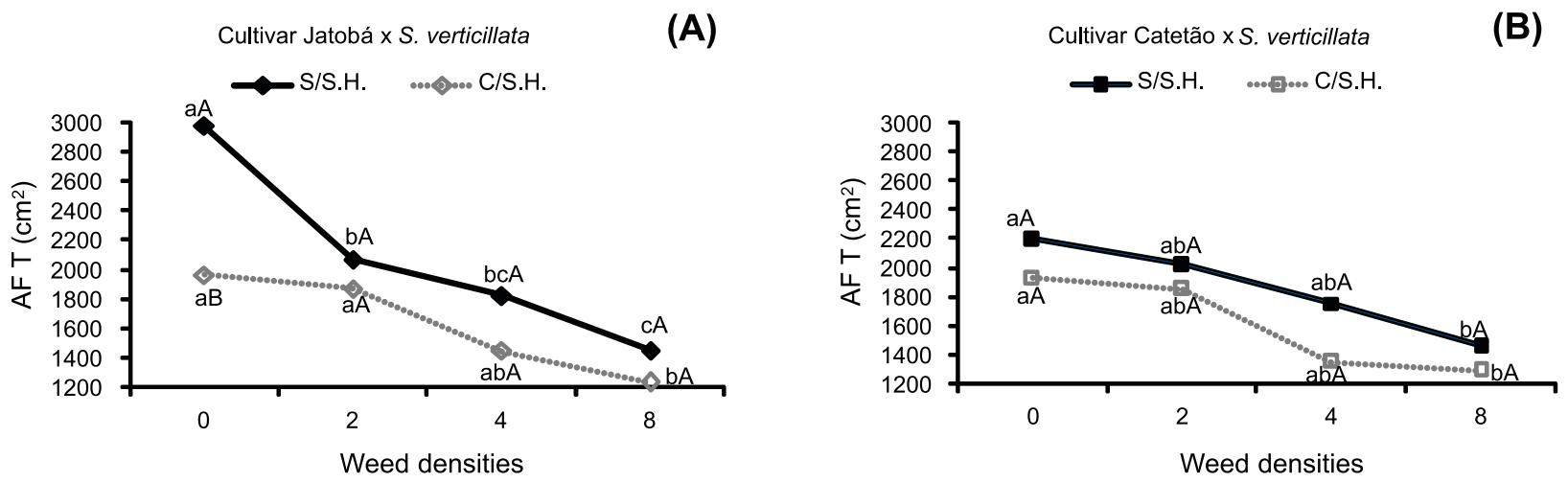

Means followed by the same lowercase letter (between the densities within each water situation) and uppercase (within each density between water conditions) did not differ statistically by Tukey test at $5 \%$ probability.

Figure 4 - Total leaf area (AFT) of rice cultivars (Jatoba and Catetão), cultivated in coexistence with different densities of S. verticillata grown at different densities under the conditions without water stress (S/S.H.) and with water stress (C/S.H.). Gurupi-TO, 2008. 
The presence of eight $S$. verticillata plants, compared to treatment without the coexistence of the weed, caused a reduction in leaf area of the cultivar Jatoba in 51.19 and $37.17 \%$ under the conditions with and without water stress, respectively. In the Catetão cultivar, the reduction was 33.60 and $33.04 \%$, respectively.
The induction of water stress and coexistence of different densities of the $S$. verticillata weed resulted in decreased accumulation of shoot dry matter (MSPA), root dry matter (MSR) and total dry matter (MST) of rice cultivars Jatoba and Catetão, as described in (Figures 5A, B, C, E and F).
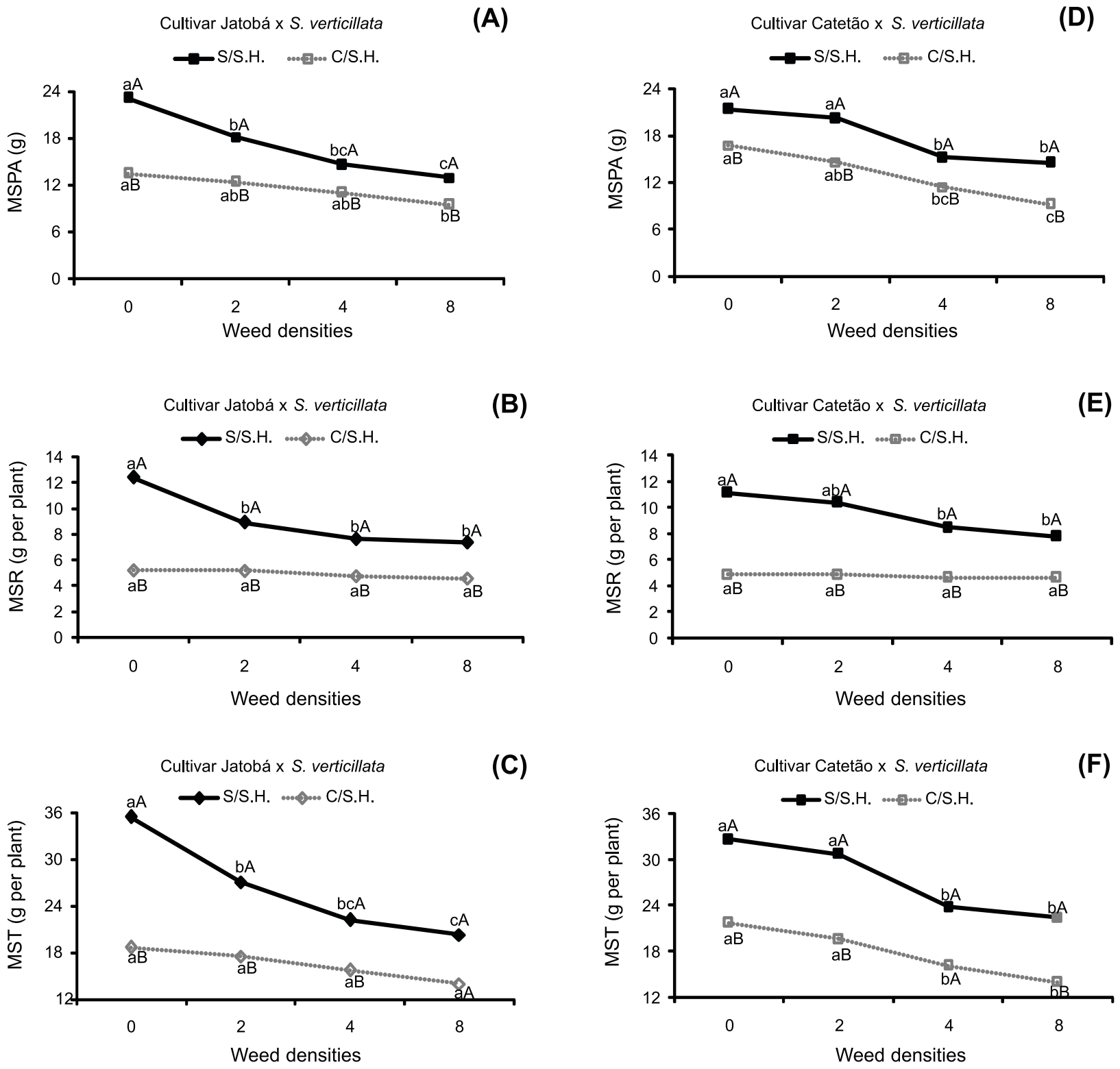

Means followed by the same lowercase letter (between the densities within each water situation) and uppercase (within each density between water conditions) did not differ statistically by Tukey test at $5 \%$ probability.

Figure 5 - Shoot dry matter (MSPA), root dry matter (MSR) and total dry matter (MST) of rice cultivars (Jatoba and Catetão), cultivated in coexistence with different densities of $S$. verticillata grown at different densities under the conditions without water stress (S/S.H.) and with water stress (C/S.H.). Gurupi-TO, 2008 
When the rice plants grew without the presence of the weed ( 0 plants per pot), the imposition of water stress caused a reduction in components MSPA, MSR and MST of the cultivar Jatoba of $41.70,58.22$ and $47.45 \%$, respectively (Figures 5A, B and $\mathrm{C}$ ). In the Catetão cultivar, the reductions were 21.60 , 56.69 and $33.61 \%$, respectively (Figures 5D, E, and $\mathrm{F}$ ).

Within each density of $S$. verticillata the water stress caused a reduction of the MSPA, MSR and MST in both rice cultivars, being significant for most treatments, regardless of the cultivar tested, except for the MST characteristic of the cultivar Jatoba in coexistence with 8 weeds per pot and the cultivar Catetão grown in coexistence with 4 weeds per pot.

The increased density of $S$. verticillata in coexistence with rice cultivars promoted a reduction of the MSPA, MSR and MST, regardless of cultivar and water condition established, but to a greater extent in the cultivar Jatoba.

Coexistence with 8 weeds per pot compared to 0 plants per pot treatment, in the condition of no water stress caused a reduction of components MSPA, MSR and MST in cultivar Jatobá in 43.81, 40.64 and $42.71 \%$, respectively. When water stress was imposed, these reductions were equivalent to $29.67,12.57$ and $24.92 \%$, respectively. The analysis for the cultivar Catetão expressed reductions in the condition without water stress in $32.04,30.22$ and $31.44 \%$, respectively, while with water stress they accounted for $44.74,4.33$ and $35.69 \%$, respectively.

The highest concentrations of roots (CR) corresponding to Jatoba and Catetão cultivars when grown without the coexistence of $S$. verticillata, in the condition of no water stress, were located at depths of 30.5 and 25.0 $\mathrm{cm}$, respectively (Figure 6A, C).

When comparing treatments with and without water stress in rice plants grown without the coexistence of the weed, there was a reduction in the concentration of roots in the order of $29.51 \%$ and $14 \%$ in cultivars Jatoba and Catetão respectively.
When the rice cultivars (Jatoba and Catetão) coexisted with 8 weeds per pot, in the absence of water stress, decreased by 18.03 and $5.0 \%$ in the concentration of roots; however, in the condition of water stress these values amounted to $13.95 \%$ and 4.65 , respectively (Figure 6A, C).

The depths of roots of rice plants in the conditions without water stress and without coexistence with the weed reached values of 105.75 and $100.5 \mathrm{~cm}$ for cultivars Jatoba and Catetão, respectively (Figure 6B, D).

In the absence of water stress, it was observed that, the higher the level of competition with $S$. verticillata, the lower the depth of the roots, regardless of the rice cultivar, when water stress was imposed and the number of weeds coexisting with rice cultivars increased, there was a response of further deepening of the roots, especially for Jatoba cultivar in the density of 8 weeds per pot.

When comparing the depth of the roots reached by the Jatoba cultiver in the 0 weeds per pot and 8 weeds per pot treatments in water stress conditions, these values were 67.50 and $110.50 \mathrm{~cm}$, respectively. In the Catetão cultivar these values were 69.25 and 96.25 $\mathrm{cm}$, respectively.

The graphical representation of the behavior of the leaf area of Spermacoce verticillata plants in different densities coexisting with two rice cultivars under two water conditions, can be seen in (Figure 7A, B).

Water stress caused a significant reduction in leaf area (AF) of $S$. verticillata in the density of 2 plants per pot coexisting with Jatoba cultivar (47.88\%). However, when in coexistence with the Catetão cultivar, though there was no significant difference, water stress reduced leaf area of the weed in $26.86 \%$.

The leaf area of $S$. verticillata at a density of 2 plants per pot was higher when grown in coexistence with the cultivar Jatoba, with values of $1,278.6$ and $486.27 \mathrm{~cm}^{2}$ in the conditions with and without water stress, respectively. However, when grown in coexistence with the Catetão cultivar, the values were 666.4 and $404.02 \mathrm{~cm}^{2}$.

Planta Daninha, Viçosa-MG, v. 31, n. 2, p. 291-302, 2013 


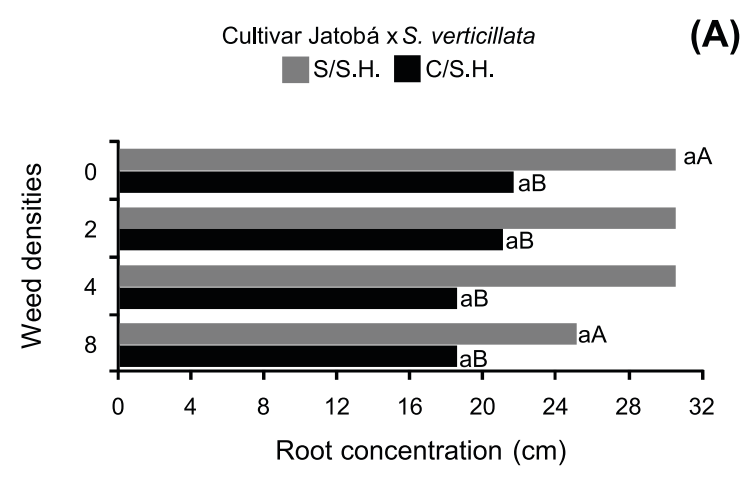

Cultivar Catetão x S. verticillata S/S.H. C C/S.H.

(C)
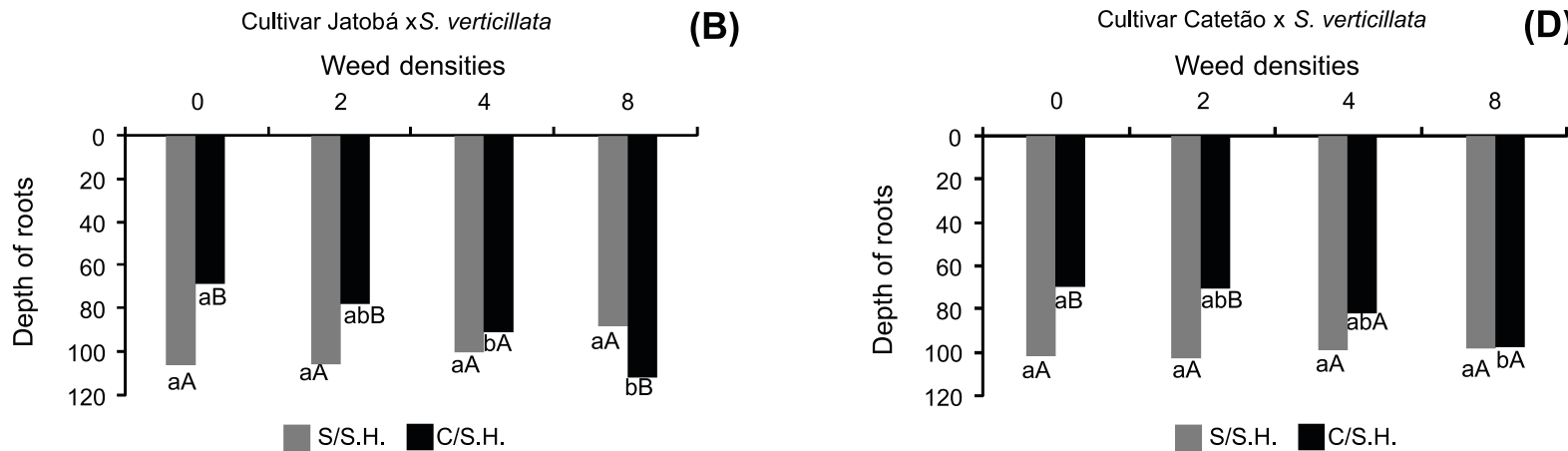

Means followed by the same lowercase letter (between the densities within each water situation) and uppercase (within each density between water conditions) did not differ statistically by Tukey test at $5 \%$ probability.

Figure 6 - Concentration of roots (CR) and root depth (PR) of rice cultivars (Jatoba and Catetão), cultivated in coexistence with different densities of $S$. verticillata grown at different densities under the conditions without water stress (S/S.H.) and with water stress (C/S.H.). Gurupi-TO, 2008.
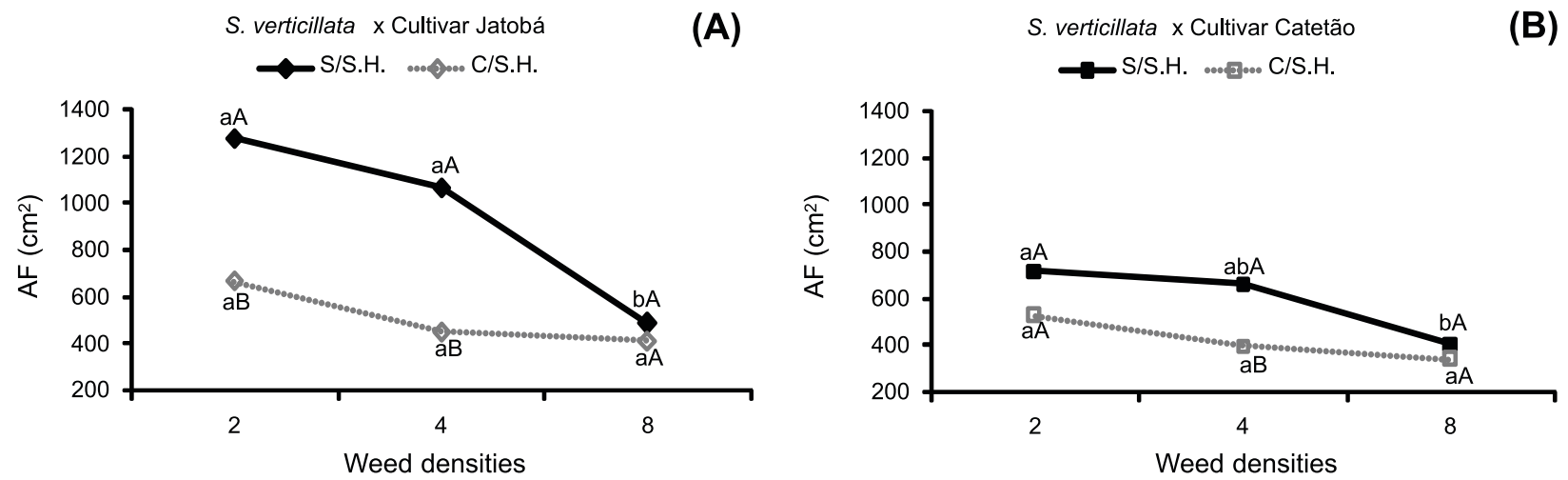

Means followed by the same lowercase letter (between the densities within each water situation) and uppercase (within each density between water conditions) did not differ statistically by Tukey test at $5 \%$ probability.

Figure 7 - Leaf area (AF) of $S$. verticillata grown at different densities, in coexistence with two rice cultivars under the conditions without water stress (S/S.H.) and with water stress (C/S.H.). Gurupi-TO, 2008.

According Taiz \& Zeiger (2004), the first responses of plants to water deficit consists in decreasing the leaf area production, stomatal closure, accelerated senescence and abscission of leaves. For Correia et al. (2004), this type of response may be associated with 
a mechanism of tolerance to water stress, and that under conditions of low water availability in the soil, plants invest more biomass in the root system, with the objective of increasing its nutrient absorption capacity.

Leaf area of $S$. verticillata decreased with increasing density per pot regardless of water condition, with only significant difference between treatments 2 and 8 plants per pot in the absence of water stress, regardless of the cultivar in coexistence.

In the treatment of higher weed density and in the absence of water stress, AF of $S$. verticillata when grown in coexistence with Jatoba cultivar was reduced by $61.97 \%$ higher than the value observed when in coexistence with the Catetão cultivar $(43.66 \%)$. When the weed coexisted under water stress, these reductions were 38.13 and $35.71 \%$, respectivasmente.

The highest values of MSPA, MSR and MST of S. verticillata, in coexistence with rice cultivars, were found in the lowest weed density, regardless of water condition (Figures 8A, B, C, D, E and F). When the plants of $S$. verticillata coexisted with the Jatoba cultivar in lower density ( 2 plants per pot), the effect of the culture under conditions of water stress caused a reduction in components MSPA, MSR and MST of the weed in 34.06, 25.58 and $32.83 \%$, respectively. In coexistence with the Catetão cultivar, these values were $3.25,5.93$ and $1.07 \%$, respectively.

This difference in reduction imposed between cultivars can be explained by lowest values of dry matter of vegetative components of the weed, recorded when it coexisted with the Catetão cultivar in conditions without water stress. Thus, the difference in values in relation to dry matter achieved in the condition with water stress was lower. This demonstrates the more competitive power of the Catetão cultivar on the weed.

In the density of 8 plants per pot of $S$. verticillata, the reduction in components MSPA, MSR and MST of the weed was 32.99, 14.26 and $30.06 \%$, respectively, when in coexistence with the rice cultivar Jatoba, but in coexistence with the cultivar Catetão, the reduction was $47.13,29.80$ and $44.36 \%$, respectively. These results highlight the higher competitive effect of the Catetão cultivar compared to Jatoba, although they may be influenced by the effect of intraspecific competition of the weed.

According to Pitelli (1985) when weeds are in low density, the interference potential of each individual can be expressed with greater intensity. Moreover, the higher the density of the weed and the further developed it is, the more intense intra and interspecific competition will be.

The higher concentration of roots $(\mathrm{CR})$ of S. verticillata was observed at $25.7 \mathrm{~cm}$ when grown in coexistence with the Jatoba cultivar, in the treatment of 2 plants per pot and in the absence of water stress, but when in coexistence with the Catetão cultivar, the highest concentration was in the first $21 \mathrm{~cm}$. Under water stress conditions, depths ranged from 23 to $22 \mathrm{~cm}$ for the Jatoba and Catetão cultivars, respectively (Figure 9A, C).

The increased density of the weed promoted a reduction in CR of $S$. verticillata, regardless of water conditions and the cultivar in coexistence, but it was not significant.

The greatest depth of the roots of S. verticillata were found in the highest density (8 plants per pot) and under water stress, with values of 95 and $93 \mathrm{~cm}$ when in coexistence with rice cultivars Jatoba and Catetão, respectively. Even at higher density, when the weed was maintained in the condition without water stress and coexisting with Jatoba and Catetão cultivars, it reached values of 82.5 and $83.25 \mathrm{~cm}$, respectively (Figure 9B, D).

Given the conditions under which the experiment was conducted, it was found that the water stress caused a reduction in leaf area, the concentration of roots and dry matter of vegetative components (APDM, MSR and MST) of cultivars Jatoba and Catetão and the $S$. verticillata. However, water stress stimulated the growth of the roots of the weed to the deepest layers of the soil. Regarding rice culture, water stress caused a reduction in root depth in almost all densities of $S$. verticillata tested, except for the treatment with greater competition for the Jatoba cultivar. 

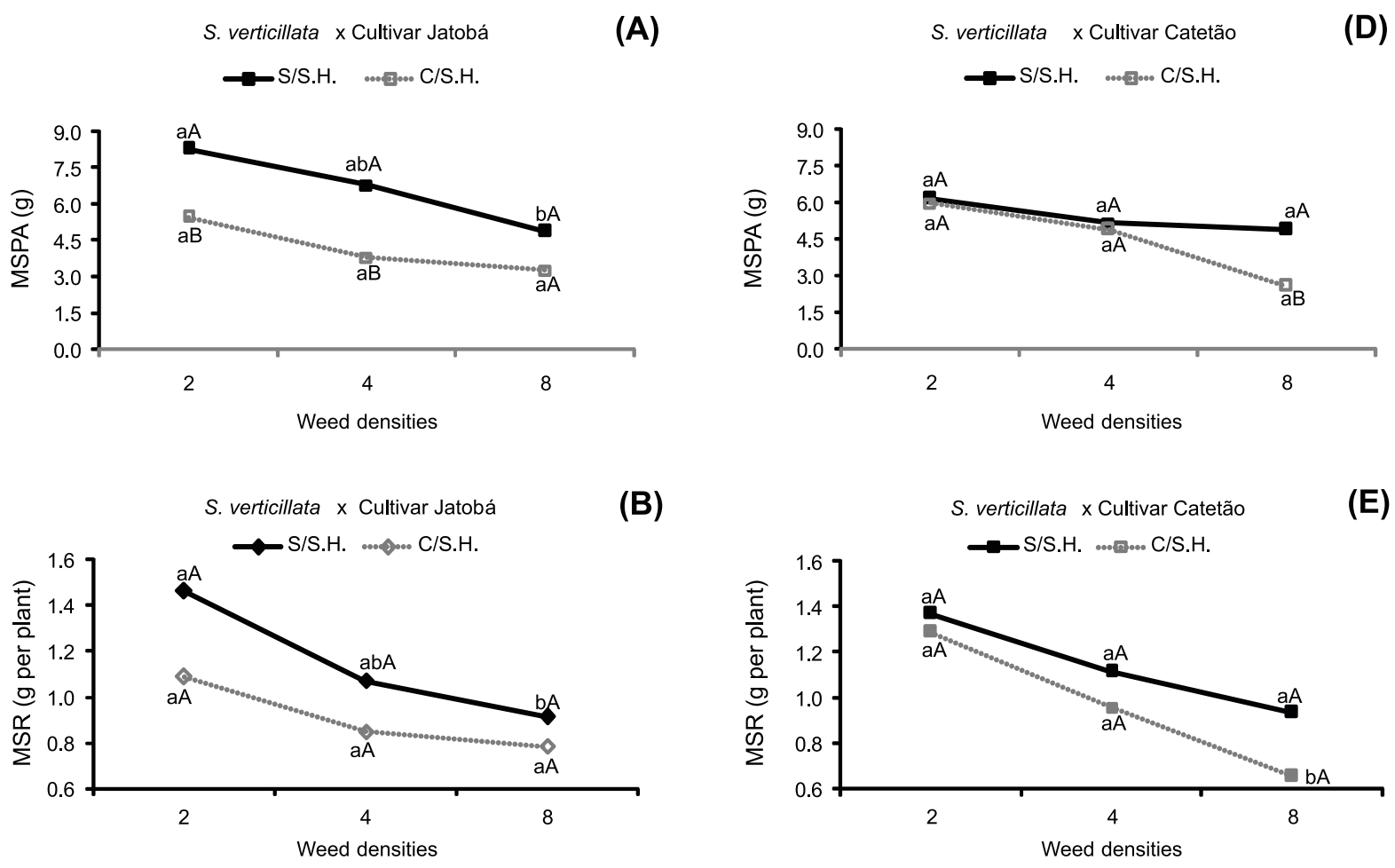

(B)
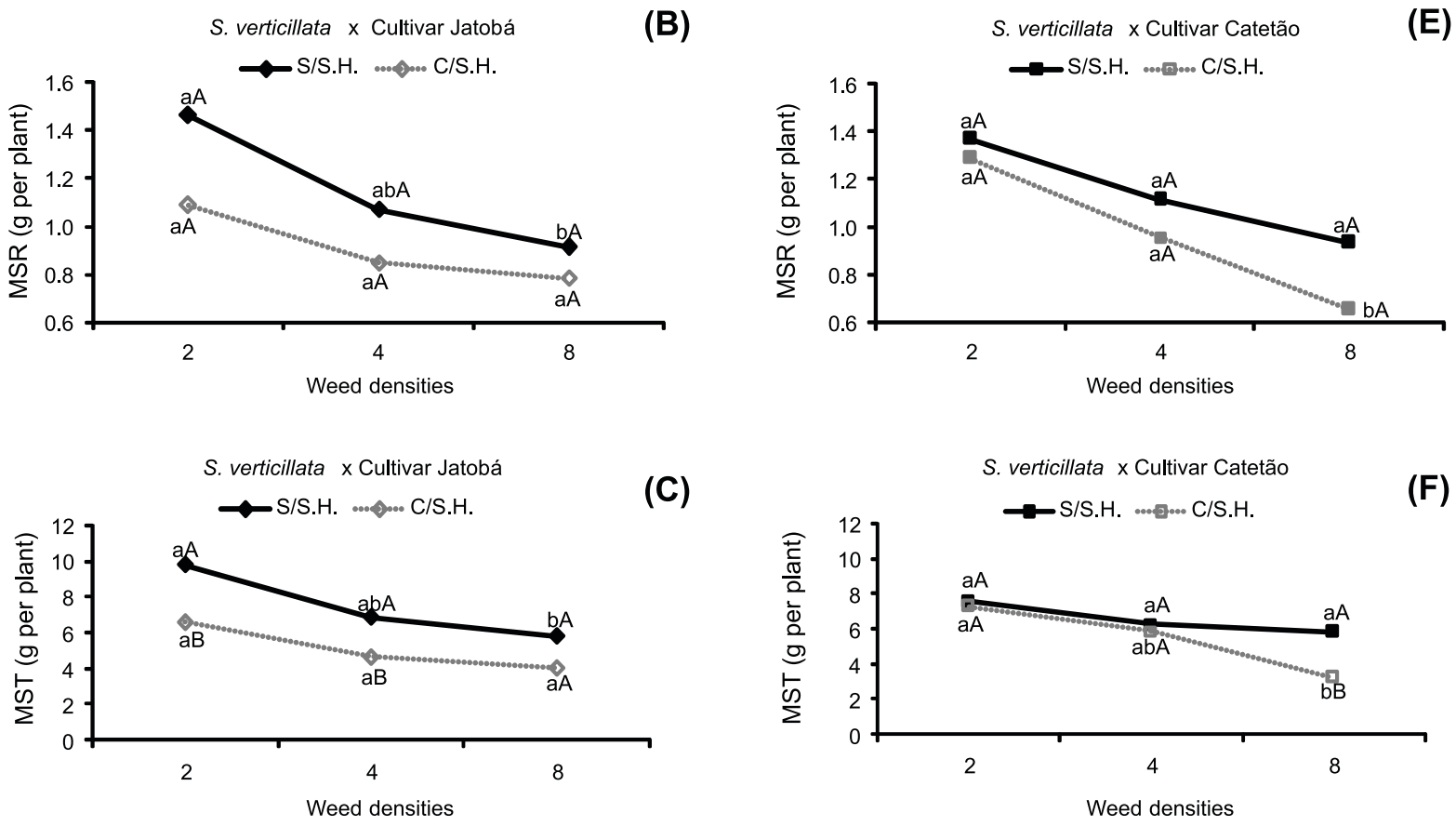

Means followed by the same lowercase letter (between the densities within each water situation) and uppercase (within each density between water conditions) did not differ statistically by Tukey test at $5 \%$ probability.

Figure 8 - Shoot dry matter (MSPA), root dry matter (MSR) and total dry matter (MST) of S. verticillata grown at different densities, in coexistence with two rice cultivars under the conditions without water stress (S/S.H.) and with water stress (C/S.H.) Gurupi-TO, 2008

The competition established by the presence of the weed provided a reduction of all vegetative components (MSPA, MSR and MST) of cultivars Jatoba and Catetão. It also decreased the number of tillers, the concentration of roots and leaf area. However, in the higher density of the weed, the Catetão cultivar produced the highest number of tillers compared to Jatoba.

At the highest level of weed competition with rice cultivars, there was a greater decrease in vegetative components and leaf area of the culture, regardless of water conditions.

As to the rice cultivars, Jatoba, in the condition without water stress and without competition, was more efficient in terms of growth and utilization of the resources of the soil in relation to Catetão; on the other hand, the latter was more competitive when exposed to the largest level of competition (8 S. verticillata plants per pot). 


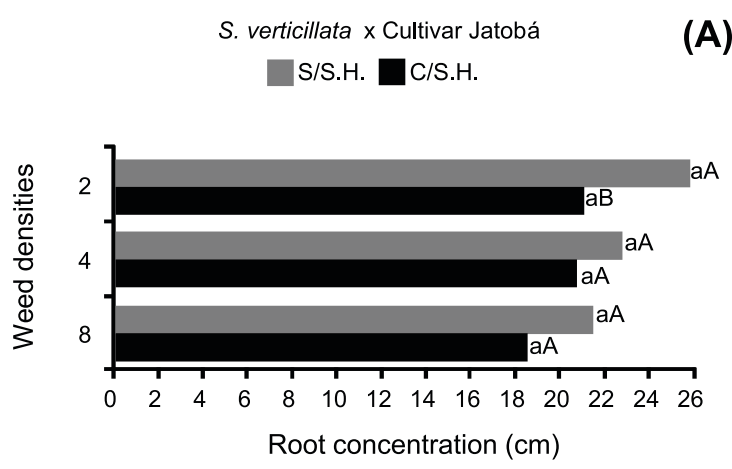

S. verticillata $\times$ Cultivar Jatobá

(B)

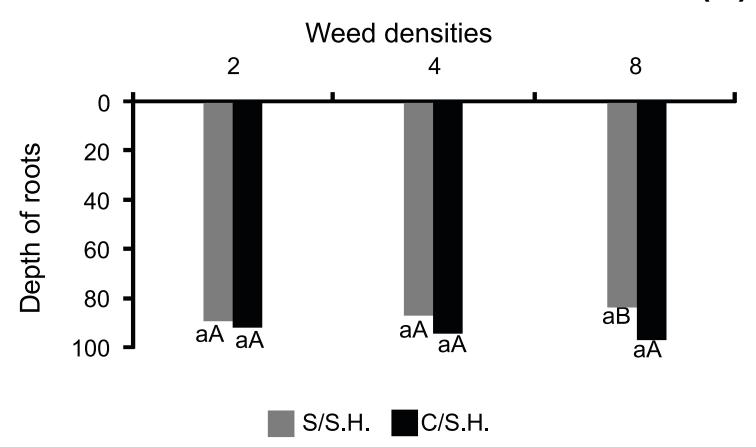

S. verticillata $\times$ Cultivar Catetão

S/S.H. $\square$ C/S.H.

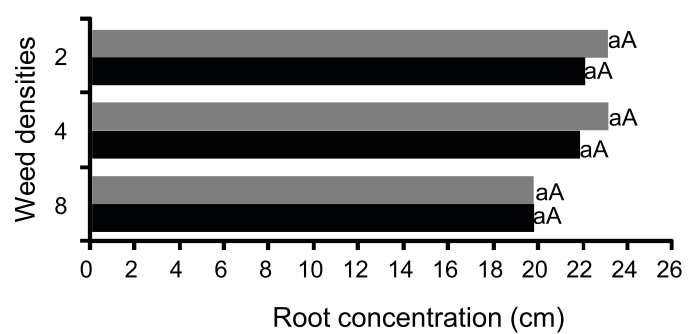

S. verticillata x Cultivar Catetão

(D)

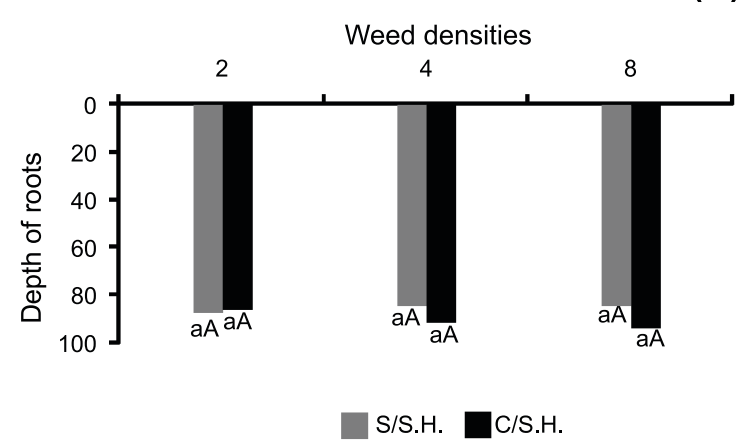

Means followed by the same lowercase letter (between the densities within each water situation) and uppercase (within each density between water conditions) did not differ statistically by Tukey test at $5 \%$ probability.

Figure 9 - Concentration of roots (CR) and root depth (PR) of $S$. verticillata grown at different densities, in coexistence with two rice cultivars under the conditions without water stress (S/S.H.) and with water stress (C/S.H.). Gurupi-TO, 2008.

\section{LITERATURE CITED}

ALCANTARA, E. N.; CARVALHO, D. A. Período de competição de plantas daninhas com arroz de sequeiro. Pesq. Agropec. Bras., v. 20, n. 5, p. 599-609, 1985.

AZEVEDO, D. M. P.; COSTA, N. L. Efeito do período de matocompetição sobre a produção do arroz de sequeiro em Porto Vermelho-RO. In: CONGRESSO BRASILEIRO DE HERBICIDAS DE PLANTAS DANINHAS, 17. 1988, Piracicaba. Resumos... Piracicaba: SBCPD, 1988. p. 51.

BALBINOT JR., A. A. et al. Características de plantas de arroz e a habilidade competitiva com plantas daninhas. Planta Daninha, v. 21, n. 2, p. 165-174, 2003.

BOUHACHE, M.; BAYER, D. E. Photosynthetic response of flooded rice (Oryza sativa) and three Echinocloa species to changes in environmental factors. Weed Sci., v. 41, p. 611-614, 1993.

CAMARA, G. et al. Spring: integrating remote sensing and GIS by object-oriented data modeling. Comp. Graphics, v. 20 , n. 3 , p. $395-403,1996$
CORREIA, K. G.; NOGUEIRA, R. J. M. C. Avaliação do crescimento do amendoim (Arachis hypogaea L.) submetido a déficit hídrico. R. Biol. Ci. Terra, v. 4, n. 2, 2004.

CRUSCIOL, C. A. C. et al. Manejo de irrigação por aspersão com base no "kc" e adubação mineral na cultura de arroz de terras altas. Bragantia, v. 62, n. 3, p. 465-475, 2003.

EMPRESA BRASILEIRA DE PESQUISA AGROPECUÁRIA - EMBRAPA. Cultivo do arroz de terras altas. Sistemas de Produção, n. 1, 2003. ISSN 16798869, Versão Eletrônica. Disponível em: <http:// sistemasdeproducao.cnptia.embrapa.br/FontesHTML/Arroz/ ArrozTerrasAltas/adubacao.ht>. Acesso em: 11 ago. 2011.

\section{EMPRESA BRASILEIRA DE PESQUISA}

AGROPECUÁRIA - EMBRAPA. Centro Nacional de Pesquisa de Solos. Sistema brasileiro de classificação de solos. Brasília: Embrapa Produção de Informação; Rio de Janeiro: Embrapa Solos, 1999. 412 p.

FORNASIERI FILHO, D.; FORNASIERI, J. L. Manual da cultura do arroz. Jaboticabal: FUNEP, 1993. 221 p.

GERIK, T. J. et al. Late season water stress in cotton: I. Plant growth, water uses, and yield. Crop Sci., v. 36, p. 914-921, 1996.

Planta Daninha, Viçosa-MG, v. 31, n. 2, p. 291-302, 2013 
PITELLI, R. A. Interferência de plantas daninhas em culturas agrícolas. Inf. Agropec., v. 11, n. 129, p. 16-27, 1985

SILVA, M. R. M. Períodos de interferência das plantas daninhas na cultura do arroz de terras altas. 2006. $100 \mathrm{f}$. Tese (Doutorado em Produção Vegetal) - Faculdade de Ciências Agrárias e Veterinárias, Jaboticabal, 2006.

SILVA, M. R. M.; DURIGAN, J. C. Períodos de interferência das plantas daninhas na cultura do arroz de terras altas. I Cultivar IAC 202. Planta Daninha, v. 24, n. 4, p. 685-694, 2006.
SILVA, S. C.; ASSAD, E. D. Zoneamento de riscos climáticos para o arroz de sequeiro nos estados de Goiás, Mato Grosso, Mato Grosso do Sul, Minas Gerais, Tocantins e Bahia.

R. Bras. Agrometeorol., v. 9, p. 536-542, 2001. (Número Especial)

STONE, L. F.; MOREIRA, J. A. A.; SILVA, S. C. Tensão da água no solo produtividade do arroz. Goiânia: Embrapa Cnpaf, 1986. 6 p. (Circular Técnica, 19)

TAIZ, L.; ZEIGER, E. Plant physiology. Redwood City: The Benjamim/Cummings Publishing Company, 2004. 719 p. 